\title{
HUBUNGAN FAKTOR INDIVIDU DAN POSTUR KERJA DENGAN KELUHAN LOW BACK PAIN PENJAHIT KECAMATAN MEDAN BARU
}

\author{
Hari Syaputra ${ }^{1}$, Mappeaty Nyorong ${ }^{2}$, Tri Niswati Utami ${ }^{3}$ \\ 1,2,3 Institut Kesehatan Helvetia, Medan. \\ Email : harisyaputra033@gmail.com
}

\begin{abstract}
Abstrak
Usaha sektor informal merupakan salah satu usaha yang memiliki risiko kesehatan yang cukup tinggi. Salah satu usaha informal yang banyak terdapat di Indonesia dan memiliki risiko kesehatan yang cukup tinggi adalah usaha menjahit. Tujuan penelitian ini untuk menganalisis hubungan faktor individu dan postur kerja dengan keluhan low back pain penjahit Kecamatan Medan Baru. Jenis penelitian ini adalah observasional analitik dengan pendekatan cross sectionalstudy. Populasi dalam penelitian ini adalah semua penjahit diKecamatan Medan Baru yang berjumlah 68 orang dengan jumlah sampel sebanyak 62 orang yang ditentukan menggunakan metode purposive sampling. Analisa menggunakan analisis univarat, bivariat dan multivariat. Hasil uji chi square menunjukkan bahwa usia $(\mathrm{p}=0,001<0,05)$, jenis kelamin $(\mathrm{p}=0,021<0,05)$, masa kerja $(\mathrm{p}=0,084>0,05)$, lama kerja $(\mathrm{p}=0,000<0,05)$ dan potur kerja $(\mathrm{p}=0,002<0,05)$. Uji regresi logistik menunjukkan bahwa variabel yang paling berpengaruh terhadap keluhan low back pain adalah lama kerja dengan nilai Exp (B) 17,170. Kesimpulan penelitian ini usia, jenis kelamin, lama kerja, postur kerja memiliki hubungan dengan keluhan low back pain, sedangkan masa kerja tidak memiliki hubungan dengan keluhan low back pain. Diperlukan upaya untuk mengurangi risiko keluhan low back pain pada pekerja dengan melakukan stretching, perbaikan terhadap keadaan duduk dan melakukan senam punggung untuk terciptanya hasil kerja yang lebih maksimal.
\end{abstract}

Kata Kunci : Usia, Jenis Kelamin, Masa Kerja, Lama Kerja, Postur Kerja

\begin{abstract}
The informal sector business is one of businesses that has a fairly high health risk. One of the informal businesses that are widely available in Indonesia and has a fairly high health risk is the sewing business. The study aimed to analyze the associated individual factors and work posture with complaints of low back pain by tailors in Medan Baru District. This study was an analytic observation with a cross-sectional study approach. The population were all tailors in Medan Baru District, amounted to 68 people with a total sample of 62 people who were determined using the purposive sampling method. The analysis used univariate, bivariate and multivariate analyses. The results of the chi-square test found the relationship this study to age $(p=.001<.05)$, gender ( $p$ $=.021<.05)$, years of service $(p=.084>0.05)$, length of service $(p=0.000<.05)$ and work posture $(p=.002<.05)$. The logistic regression test showed that the most influential variable on complaints of low back pain was length of work with an Exp $(B)$ value of 17.170. The conclusion showed that age, gender, length of work, work posture have a relationship with complaints of low back pain, while tenure had no relationship with complaints of low back pain. It is suggested to do stretching, improving the sitting state and doing back exercises to reduce the back pain complaint and maximum good work.
\end{abstract}

Keywords: Age, Gender, Working Period, Length of Work, Work Posture

\section{Pendahuluan}

Memasuki era globalisasi yang merupakan era perdagangan bebas pada semua bidang, menimbulkan persaingan antara tenaga kerja khususnya pada sektor formal. Kondisi ini pun mendorong sebagian dari golongan masyarakat membuka usaha di sektor 
informal untuk memperoleh penghasilan baik bagi dirinya sendiri maupun untuk keluarganya (Ayu \& Ayu, 2018). Dalam menjalani pekerjaan, manusia hampir sebagian besar menghabiskan waktunya ditempat kerja. Lingkungan tempat kerja menjadi salah satu tempat yang mempunyai risiko terhadap kesehatan orang-orang yang bekerja di lingkungan tersebut (Aminoto, dkk, 2017).

Kejadian kecelakaan kerja/penyakit akibat kerja sering terjadi di sektor informal, hal ini dikarenakan para pekerja di sektor informal masih belum memahami tentang Keselamatan dan Kesehatan Kerja (K3), sehingga upaya dalam pelaporan dan pengawasan K3 masih perlu mendapatkan perhatian khusus (Ayu \& Ayu, 2018).

International Labor Organization (ILO) menyatakan terdapat 1 pekerja di dunia meninggal setiap 15 detik akibat kecelakaan kerja dan 160 pekerja mengalami sakit akibat kerja. ILO mencatat angka kematian akibat kecelakaan dan penyakit akibat kerja sebanyak 2 juta kasus setiap tahun (Sujono, dkk, 2018).

Di Negara Indonesia menjahit menjadi pekerjaan yang ditekuni oleh banyak orang, baik individu maupun usaha konveksi. Kelompok pekerja ini sering mengalami keadaan postur yang kaku dan beban otot yang statis akibat tugas yang berulang-ulang dengan kecepatan produksi yang tinggi. Menjahit dilakukan dalam posisi duduk dengan cukup lama, kurang lebih 4-8 jam per hari dan dilakukan terus menerus dengan posisi membungkuk. Duduk lama pada penjahit dengan posisi yang salah dapat mengakibatkan timbulnya keluhan rasa sakit seperti ngilu dan keram otot(Nurul, 2019).

Low Back Pain (LBP) merupakan rasa nyeri yang dirasakan pada punggung bawah yang sumbernya adalah tulang belakang daerah spinal atau punggung bawah, otot, saraf, atau struktur daerah lainnya di daerah tersebut. gejala low back pain diantaranya nyeri otot, rasa tidak nyaman atau nyeri di daerah pinggang, nyeri yang menjalar ke tungkai bawah sampai ke kaki, serta kesulitan untuk berdiri tegak. Low back pain merupakan salah satu gangguan yang disebabkan oleh aktivitas tubuh yang kurang baik (Riningrum, 2016).

Permasalahan Low Back Pain yang timbul pada pekerja biasanya sering diabaikan karena sebagian besar pekerja menyalahartikan nyeri pada tulang punggung bawah yang biasanya para pekerja mengeluhkan rasa lelah, namun Low Back Pain merupakan gangguan kesehatan yang disebabkan dari aktivitas pekerjaan seperti duduk terlalu lama, mengangkat dan mengangkut material pekerjaan yang dilakukan secara manual dilakukan secara berulang-ulang ( Ayu \& Ayu, 2018).

Berdasarkan Penelitian sebelumnya yang dilakukan oleh Damayanti (2021) menyatakan bahwa faktor keluhan low back pain banyak terjadi akibat pengaruh lama duduk, sikap kerja, beban kerja dan posisi/sikap duduk (Damayanti, 2021).

Duduk lama dengan posisi yang salah dapat menyebabkan otot-otot pinggang menjadi tegang dan dapat merusak jaringan lunak sekitarnya. Melakukan aktivitas dengan posisi duduk yang monoton lebih dari 2 jam dalam sehari dapat meningkatkan resiko timbulnya nyeri punggung (Jahidin, 2009).

Studi pendahuluan yang dilakukan peneliti pada sektor usaha informal Kecamatan Medan Baru dengan mewawancarai 10 orang penjahit pakaian diperoleh keterangan bahwa dari 10 orang penjahit, 9 diantaranya pernah memiliki keluhan nyeri punggung bawah saat bekerja mengoperasikan mesin jahit. Peneliti menemukan bahwa penjahit berjenis kelamin wanita dan laki-laki, memiliki usia dan masa kerja yang berbeda-beda. Penjahit bekerja rata-rata selama 5-8 jam perhari dengan posisi kerja duduk membungkuk kedepan dan kepala menunduk.

Hasil survei awal yang dilakukan peneliti menggunakan pengisian lembar Nordic Body Map dan Rapid Entire Body Assessment yang dilakukan pada 10 orang penjahit pakaian dengan jenis jahitan dan jumlah orderan yang sama setiap harinya diperoleh keterangan pada pengisian NBP menunjukkan bahwa para penjahit yang memiliki keluhan 
bagian leher (30\%), bahu (30\%), punggung (60\%), lengan (20\%) pinggang $(70 \%)$, bokong $(60 \%)$, siku (20\%), paha (40\%), lutut (50\%), betis (40\%) dan kaki (30\%). Sedangkan hasil dari kuesioner REBA menunjukkan bahwa mayoritas penjahit tidak merubah posisi saat membungkuk ke posisi duduk tegak ketika bekerja setelah 15-20 menit (40\%), Saat bekerja melakukan posisi duduk yang lama (70\%), melakukan posisi statis (tidak bergerak, tidak berubah) saat bekerja selama 15-20 menit (50\%) dan melakukan pergerakan berulang $>4 \mathrm{x}$ dalam 1 menit (40\%).

Berdasarkan pemaparan diatas penulis tertarik melakukan penelitian dengan judul "Hubungan Faktor Individu dan Postur Kerja dengan Keluhan Low Back Pain Penjahit Kecamatan Medan Baru".

\section{Metode Penelitian}

Jenis penelitian ini adalah observasional analitik dengan desain cross sectional study, yaitu penelitian yang dilakukan dengan cara pengumpulan data sekaligus pada suatu waktu dengan melakukan observasi dan pengukuran variabel. Tempat penelitian di Kecamatan Medan Baru dilakukan penelitian selama 6 bulan mulai dari bulan Mei hingga Oktober 2021. Populasi dalam penelitian ini semua penjahit dikecamatan Medan baru berjumlah 68 orang dengan jumlah sampel sebanyak 62 orang yang di tentukan menggunakan metode purposive sampling. Analisis data menggunakan analisis univarat menjabarkan secara deskriftif mengenai distribusi berdasarkan faktor individu yakni usia, jenis kelamin, masa kerja, lama kerja, postur kerja, dan serta risiko Low Back Pain. Bivariat untuk mengetahui besarnya pengaruh antara dua variabel independen dengan variabel dependen. Analisis Multivariat untuk melihat kemaknaan pengaruh antara variabel bebas dengan variabel terikat dilokasi penelitian secara simulta sekaligus menentukan faktorfaktor yang lebih domain berhubungan dengan keluhan Low Back Pain. Uji statistik yang digunakan adalah regresi logistik pada pada batas kemaknaan $95 \%$ dengan perhitungan statistik $\alpha=0,05$.

\section{Hasil Penelitian}

\section{Analisis Univariat}

Tabel 1. Distribusi Frekuensi Berdasarkan Usia Penjahit di Kecamatan Medan Baru

\begin{tabular}{cccc} 
No & Usia & F & Jumlah \\
& & 23 & \% \\
\hline 1. & Kurang Berisiko $(<35$ tahun $)$ & 39 & 37,1 \\
2. & Berisiko $(\geq 35$ tahun $)$ & $\mathbf{6 2}$ & $\mathbf{1 0 0}$
\end{tabular}

Tabel 2. Distribusi Frekuensi Berdasarkan Jenis Kelamin Penjahit di Kecamatan Medan

\begin{tabular}{|c|c|c|c|}
\hline \multirow[b]{2}{*}{ No } & \multirow[b]{2}{*}{ Jenis Kelamin } & & \\
\hline & & \multicolumn{2}{|c|}{ Jumlah } \\
\hline 1. & Laki-laki & 8 & 12,9 \\
\hline 2. & Perempuan & 54 & 87,1 \\
\hline & Jumlah & 62 & 100 \\
\hline
\end{tabular}

Tabel 3. Distribusi Frekuensi Berdasarkan Masa Kerja Penjahit di Kecamatan Medan Baru

\begin{tabular}{cccc} 
No & Masa Kerja & f & Jumlah \\
\hline 1. & Baru $(<3$ tahun $)$ & 25 & \% \\
2. & Lama $(\geq 3$ tahun $)$ & 37 & 40,3 \\
\hline & Jumlah & $\mathbf{6 2}$ & $\mathbf{1 0 0}$
\end{tabular}


Tabel 4. Distribusi Frekuensi Berdasarkan Lama Kerja Penjahit di Kecamatan Medan Baru

\begin{tabular}{cccc} 
No & Lama Kerja & f & Jumlah \\
\hline 1. & Sesuai $(<6$ jam/hari $)$ & 26 & \% \\
2. & Kurang Sesuai $(\geq 6$ jam/hari $)$ & 36 & 58,1 \\
\hline & Jumlah & $\mathbf{6 2}$ & $\mathbf{1 0 0}$
\end{tabular}

Tabel 5. Distribusi Frekuensi Berdasarkan Postur Kerja Penjahit di Kecamatan Medan Baru

\begin{tabular}{cccc} 
No & Postur Kerja & f & Jumlah \\
& & $\mathbf{\%}$ \\
\hline 1. & Risiko Sedang & 29 & 46,8 \\
2. & Risiko Tinggi & 33 & 53,2 \\
\hline & Jumlah & $\mathbf{6 2}$ & $\mathbf{1 0 0}$
\end{tabular}

Tabel 6. Distribusi Frekuensi Jawaban Responden Berdasarkan Item Pertanyaan Keluhan Low Back Pain Penjahit di Kecamatan Medan Baru

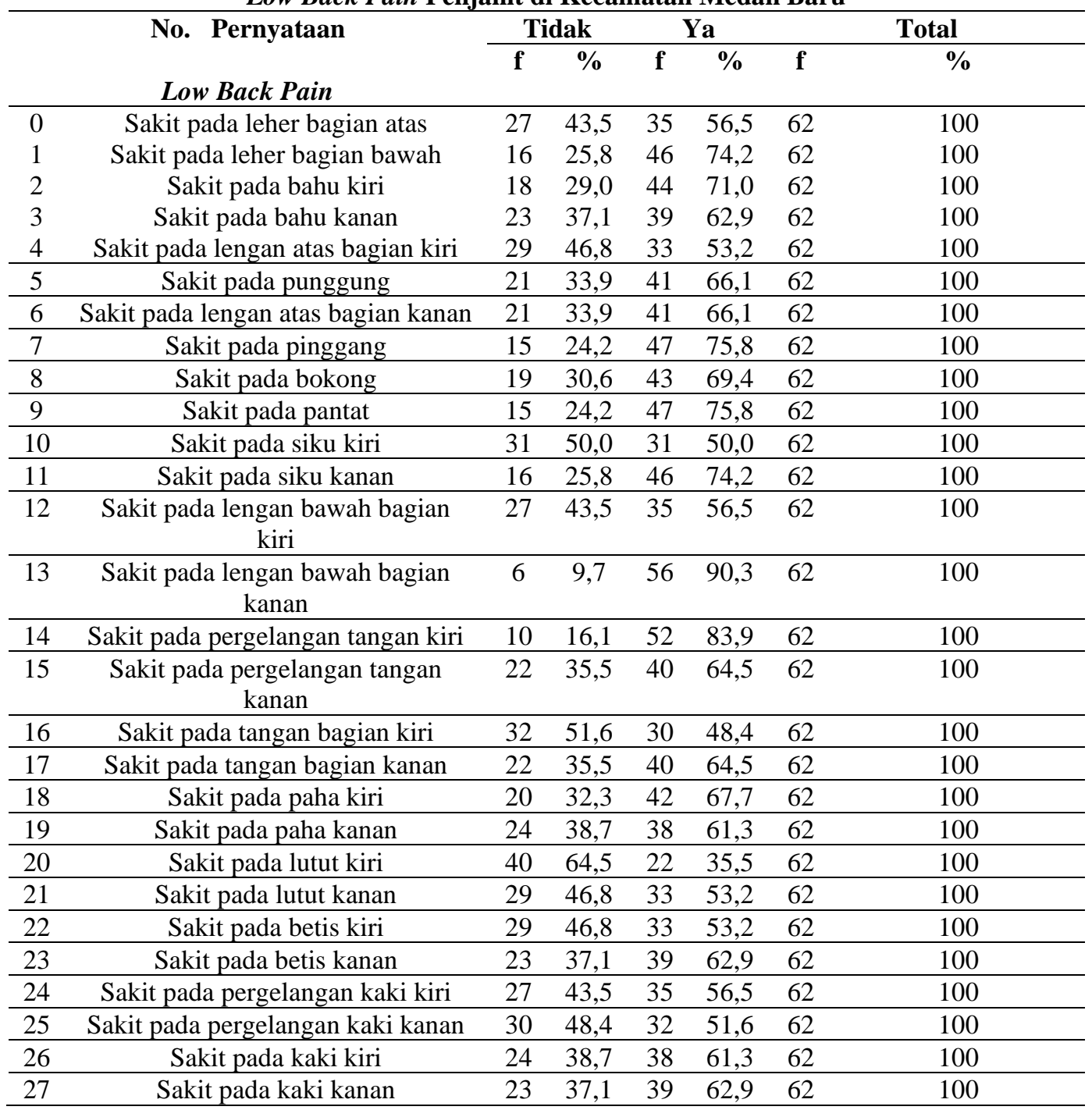




\section{MIRACLE JOURNAL

Tabel 7. Distribusi Frekuensi Berdasarkan Keluhan Low Back Pain Penjahit di Kecamatan Medan Baru

\begin{tabular}{cccc} 
No & Keluhan Low Back Pain & f & Jumlah \\
& & 23 & \% \\
\hline 1. & Tidak Ada Keluhan & 39 & 37,1 \\
2. & Ada Keluhan & $\mathbf{6 2}$ & $\mathbf{1 0 0}$
\end{tabular}

Analisa Bivariat

Hasil analisa bivariat pada penelitian ini dapat dilihat pada tabel berikut.

Tabel 8. Tabulasi Silang Hubungan Usia dengan Keluhan Low Back Pain Penjahit di Kecamatan Medan Baru

\begin{tabular}{|c|c|c|c|c|c|c|c|c|}
\hline \multirow{3}{*}{ No } & \multirow{3}{*}{ Usia } & \multicolumn{4}{|c|}{ Keluhan Low Back Pain } & \multirow{2}{*}{\multicolumn{2}{|c|}{ Total }} & \multirow[t]{3}{*}{ p (sig) } \\
\hline & & \multicolumn{2}{|c|}{ Tidak } & \multicolumn{2}{|c|}{ Ada } & & & \\
\hline & & $\mathbf{F}$ & $\%$ & $\mathbf{f}$ & $\%$ & f & $\%$ & \\
\hline \multirow[t]{2}{*}{1.} & Kurang & 15 & 24,1 & 8 & 13 & 23 & 37 & \multirow{3}{*}{0,001} \\
\hline & Berisiko & & & & & & & \\
\hline \multirow[t]{2}{*}{2.} & Berisiko & 8 & 12,9 & 31 & 50 & 39 & 63 & \\
\hline & Total & 23 & 37 & 39 & 63 & 62 & 100 & \\
\hline
\end{tabular}

Tabel 9. Tabulasi Silang Hubungan Jenis Kelamin dengan Keluhan Low Back Pain Penjahit di Kecamatan Medan Baru

\begin{tabular}{|c|c|c|c|c|c|c|c|c|}
\hline \multirow{3}{*}{ No } & \multirow{3}{*}{ Jenis Kelamin } & \multicolumn{4}{|c|}{ Keluhan Low Back Pain } & \multirow{2}{*}{\multicolumn{2}{|c|}{ Total }} & \multirow[t]{3}{*}{ p (sig) } \\
\hline & & \multicolumn{2}{|c|}{ Tidak } & \multicolumn{2}{|c|}{ Ada } & & & \\
\hline & & $\mathbf{F}$ & $\%$ & f & $\%$ & f & $\%$ & \\
\hline 1. & Laki-laki & 0 & 0 & 8 & 13 & 8 & 13 & \multirow{2}{*}{0,021} \\
\hline \multirow[t]{2}{*}{2.} & Perempuan & 23 & 37 & 31 & 50 & 54 & 87 & \\
\hline & Total & 23 & 37 & 39 & 63 & 62 & 100 & \\
\hline
\end{tabular}

Tabel 10. Tabulasi Silang Hubungan Masa Kerja dengan Keluhan Low Back Pain Penjahit di Kecamatan Medan Baru

\begin{tabular}{|c|c|c|c|c|c|c|c|c|}
\hline \multirow{3}{*}{ No } & \multirow{3}{*}{ Masa Kerja } & \multicolumn{4}{|c|}{ Keluhan Low Back Pain } & \multirow{2}{*}{\multicolumn{2}{|c|}{ Total }} & \multirow[t]{3}{*}{ p (sig) } \\
\hline & & \multicolumn{2}{|c|}{ Tidak } & \multicolumn{2}{|c|}{ Ada } & & & \\
\hline & & $\mathbf{F}$ & $\%$ & $\mathbf{f}$ & $\%$ & $\mathbf{f}$ & $\%$ & \\
\hline 1. & $\begin{array}{c}\text { Baru } \\
(<3 \text { tahun })\end{array}$ & 13 & 21 & 12 & 19,3 & 25 & 40,3 & \\
\hline 2. & $\begin{array}{c}\text { Lama } \\
(\geq 3 \text { tahun) }\end{array}$ & 10 & 16 & 27 & 43,7 & 37 & 59,7 & 0,084 \\
\hline & Total & 23 & 37 & 39 & 63 & 62 & 100 & \\
\hline
\end{tabular}

Tabel 11. Tabulasi Silang Hubungan Lama Kerja dengan Keluhan Low Back Pain Penjahit

\begin{tabular}{|c|c|c|c|c|c|c|c|c|}
\hline \multirow{3}{*}{ No } & \multirow{3}{*}{ Lama Kerja } & \multicolumn{4}{|c|}{ Keluhan Low Back Pain } & \multirow{2}{*}{\multicolumn{2}{|c|}{ Total }} & \multirow[t]{3}{*}{ p (sig) } \\
\hline & & \multicolumn{2}{|c|}{ Tidak } & \multicolumn{2}{|c|}{ Ada } & & & \\
\hline & & $\mathbf{F}$ & $\%$ & $\mathbf{f}$ & $\%$ & f & $\%$ & \\
\hline 1. & $\begin{array}{c}\text { Sesuai } \\
(<6 \text { iam/hari) }\end{array}$ & 19 & 30,6 & 7 & 11,3 & 26 & 42 & \\
\hline 2. & $\begin{array}{l}\text { Kurang Sesuai } \\
\text { ( } \geq 6 \text { jam/hari) }\end{array}$ & 4 & 6,4 & 32 & 51,7 & 36 & 58 & 0,000 \\
\hline & Total & 23 & 37 & 39 & 63 & 62 & 100 & \\
\hline
\end{tabular}


Tabel 12. Tabulasi Silang Hubungan Postur Kerja dengan Keluhan Low Back Pain Penjahit di Kecamatan Medan Baru

\begin{tabular}{|c|c|c|c|c|c|c|c|c|}
\hline \multirow{3}{*}{ No } & \multirow{3}{*}{ Postur Kerja } & \multicolumn{4}{|c|}{ Keluhan Low Back Pain } & \multirow{2}{*}{\multicolumn{2}{|c|}{ Total }} & \multirow[t]{3}{*}{ p (sig } \\
\hline & & \multicolumn{2}{|c|}{ Tidak } & \multicolumn{2}{|c|}{ Ada } & & & \\
\hline & & $\mathbf{F}$ & $\%$ & $\mathbf{f}$ & $\%$ & $\mathbf{f}$ & $\%$ & \\
\hline 1. & Risiko Sedang & 17 & 27,3 & 12 & 19,4 & 29 & 46,7 & \multirow{2}{*}{0,002} \\
\hline 2. & Risiko Tinggi & 6 & 9,7 & 27 & 43,6 & 33 & 53,3 & \\
\hline & Total & 23 & 37 & 39 & 63 & 62 & 100 & \\
\hline
\end{tabular}

\section{Analisis Multivariat}

\section{Seleksi Kandidat}

Pada tahap ini dilakukan seleksi variabel independen manakah yang layak masuk model uji multivariat. Dimana yang layak adalah yang memiliki tingkat signifikan (sig.) atau $p$ value $<0,25$, dengan metode "Enter" dalam regresi logistik, yaitu dengan melakukan satu persatu regresi logistik antara masing-masing variabel independen terhadap variabel dependen.

\begin{tabular}{ccc}
\multicolumn{2}{c}{ Tabel 13. Hasil seleksi Bivariat Variabel Independen Dengan Variabel Dependen } \\
\hline No & Subvariabel & $\boldsymbol{p}$-value \\
\hline 1. & Usia & 0,001 \\
2. & Jenis Kelamin & 0,021 \\
3. & Masa Kerja & 0,084 \\
4. & Lama Kerja & 0,000 \\
5. & Postur Kerja & 0,002 \\
\hline
\end{tabular}

\section{Uji Regresi Logistik Tahap Pertama}

Adapun variabel yang di uji pada regresi logistik tahap pertama ini adalah seluruh variabel independen yang telah dinyatakan memiliki nilai $p$-value $<0,25$ pada analisis bivariat yaitu usia, jenis kelamin, masa kerja, lama kerja dan postur kerja.

Tabel 14. Hasil Uji Regresi Tahap Pertama

\begin{tabular}{|c|c|c|c|c|c|c|}
\hline \multirow[b]{2}{*}{ No } & \multirow[b]{2}{*}{ Variabel Penelitian } & \multirow[b]{2}{*}{ Df } & \multirow[b]{2}{*}{ Sig. } & \multirow[b]{2}{*}{$\operatorname{Exp}(\mathbf{B})$} & \multicolumn{2}{|c|}{ 95\% C.I.for $\operatorname{Exp(B)}$} \\
\hline & & & & & Lower & Upper \\
\hline 1. & Usia & 1 & 0,031 & 7,665 & 1,198 & 49,037 \\
\hline 2. & Jenis Kelamin & 1 & 0,999 & 0,000 & 0,000 & \\
\hline 3. & Masa Kerja & 1 & 0,617 & 0,607 & 0,086 & 4,290 \\
\hline 4. & Lama Kerja & 1 & 0,001 & 21,663 & 3,302 & 142,139 \\
\hline 5. & Postur Kerja & 1 & 0,601 & 0,56 & 0,061 & 5,022 \\
\hline & Constant & 1 & 0,999 & 0,999 & & \\
\hline
\end{tabular}

\section{Uji Regresi Logistik Tahap Kedua}

Berdasarkan analisis tahap pertama terdapat 2 variabel yang memenuhi syarat $p$-value $<$ 0,05 untuk dilakukan uji tahap kedua yaitu variabel usia dan lama kerja.

Tabel 15. Hasil Uji Regresi Tahap Kedua

\begin{tabular}{ccccccc} 
& & & & \multicolumn{2}{c}{$\mathbf{9 5 \%}$ C.I.for $\operatorname{Exp}(\mathbf{B})$} \\
No & Variabel Penelitian & Df & Sig. & $\operatorname{Exp}(B)$ & Lower & Upper \\
1. & Usia & 1 & 0,028 & 4,915 & 1,191 & 20,282 \\
2. & Lama Kerja & 1 & 0,000 & 17,170 & 4,151 & 71,015 \\
& Constant & 1 & 0,000 & 0,002 & &
\end{tabular}

\section{Persamaan Regresi}

Persamaan regresi logistik dibuat untuk melihat kemampuan variabel independen dalam menjelaskan variabel dependen tentang keluhan low back pain. Pada penelitian ini sesuai 
dengan rumus persamaan regresinya adalah sebagai berikut :

Keterangan :

$$
\ln \left[\frac{\rho}{1-\rho}\right]=B 0+B 1 X
$$

$$
\begin{aligned}
& \text { Ln } \quad \text { Logaritma Natural } \\
& \text { B0 + B1X : Persamaan yang biasa dikenal dalam OLS } \\
& \text { Hasil rumus diatas dapat dilihat pada tabel di bawah ini : }
\end{aligned}
$$

Tabel 16. Tabel Hasil Analisis Regresi Logistik Model Summary

\begin{tabular}{ccc}
\hline $\mathbf{- 2}$ Log likelihood & Cox \& Snell R Square & Nagelkeker R Square \\
\hline $50.369^{\mathrm{a}}$ & .397 & .542 \\
\hline
\end{tabular}

\section{Pembahasan}

\section{Analisis Hubungan Usia dengan Keluhan Low Back Pain Penjahit di Kecamatan Medan Baru}

Hasil penelitian ini sejalan dengan penelitian yang dilakukan oleh Bilondatu (2018) dengan judul "Faktor Yang Berhubungan Dengan Kejadian Low Back Pain pada Operator Alat Angkat Angkut PT. Terminal Petikemas Makassar" yang menunjukkan bahwa ada hubungan antara umur dengan low back pain pada Operator PT. Terminal Peti kemas Makassar Tahun 2018. Dari hasil ini dapat diketahui bahwa semakin tinggi umur seseorang maka semakin tinggi pula tingkat kejadian low back pain yang dialaminya (Bilondatu, 2018).

Menurut asumsi peneliti dari hasil penelitian didapatkan keterangan bahwa mayoritas penjahit memiliki usia dengan kategori berisiko yaitu berusia $\geq 35$ tahun mengalami keluhan Low Back Pain dengan kategori berat. Dikarenakan tidak ada batasan umur bagi para penjahit sehingga pekerjaaan menjahit dapat dilakukan siapa saja yang memiliki keterampilan menjahit. Semakin bertambahnya usia maka semakin besar kemungkinan seseorang untuk mengalami keluhan Low Back Pain. Hal ini disebabkan kekuatan dan ketahanan otot mulai menurun sehingga risiko terjadinya keluhan otot semakin meningkat yang dapat berdampak pada efektivitas kerja.

Peneliti menemukan bahwa penjahit dengan usia muda yang mengalami keluhan Low Back Pain dapat terjadi karena dipengaruhi oleh waktu kerja yang tergolong lama dan postur kerja penjahit yang kurang baik selama mengoperasikan mesin jahit, begitu pula sebaliknya penjahit yang memiliki usia dengan kategori berisiko namun tidak mengalami keluhan Low Back Pain dapat terjadi karena dipengaruhi oleh waktu kerja yang tergolong normal dan postur kerja penjahit yang baik selama mengoperasikan mesin jahit.

\section{Analisis Hubungan Jenis Kelamin dengan Keluhan Low Back Pain Penjahit di} Kecamatan Medan Baru

Secara fisiologis kemampuan otot wanita lebih rendah daripada pria. Pada wanita keluhan ini sering terjadi misalnya pada saat mengalami siklus menstruasi, selain itu proses menopause juga dapat menyebabkan kepadatan tulang berkurang akibat penurunan hormon esterogen sehingga memungkinkan terjadinya nyeri punggung (Wijayanti, dkk, 2019).

Hasil penelitian ini tidak sejalan dengan penelitian yang dilakukan oleh Ulandari (2017) yang berjudul "Analisis Postur Kerja Dengan Keluhan Low Back Pain Pada Pekerja Pencetak Genteng Di Kabupaten Blitar" menunjukkan bahwa tidak ada hubungan antara jenis kelamin dengan low back pain pada pekerja pencetak genteng di kabupaten blitar(Ulandari, 2017). 
Menurut asumsi peneliti dari hasil penelitian didapatkan keterangan bahwa mayoritas penjahit memiliki jenis kelamin perempuan dengan keluhan low back pain kategori berat. Pekerjaan menjahit tidak memandang gender, baik laki-laki atau perempuan dapat melakukan pekerjaan menjahit jika memiliki keterampilan. Penyakit akibat kerja menjadi salah satu penyakit yang mempunyai agen penyebab yang sudah diakui dimana faktor pekerjaan memegang peranan bersama dengan faktor risiko lain dalam berkembangnya penyakit yang mempunyai etiologi yang kompleks.

Faktor jenis kelamin memiliki hubungan dengan terjadinya low back pain (LBP) yang disebabkan karena kemampuan otot wanita lebih rendah dibandingkan dengan lakilaki. Selain itu, pada saat mengalami siklus menstruasi dan proses menopause juga dapat menyebabkan kepadatan tulang pada wanita berkurang akibat penurunan hormon esterogen sehingga memungkinkan terjadinya nyeri punggung. Sehingga low back pain (LBP) lebih sering terjadi pada wanita daripada laki-laki.

Peneliti menemukan bahwa seluruh penjahit wanita telah mengalami proses menstruasi, mayoritas penjahit wanita sudah menikah dan mengalami proses bersalin dan menyusui. Selain itu, beberapa penjahit wanita mengaku sudah berada pada fase menopause.

\section{Analisis Hubungan Masa Kerja dengan Keluhan Low Back Pain Penjahit di Kecamatan Medan Baru}

Masa kerja yang lama akan mengakibatkan rongga diskus menyempit secara permanen dan akan mengakibatkan degenerasi tulang belakang yang akan menyebabkan Low Back Pain.

Hasil penelitian ini tidak sejalan dengan penelitian yang dilakukan oleh Rohmawan dan Hariyono (2017) dengan judul "Hubungan Masa Kerja dan Sikap Kerja dengan Keluhan Low Back Pain pada Pekerja Bagian Produksi PT Surya Besindo Sakti Kabupaten Serang" yang menunjukkan bahwa Ada hubungan antara masa kerja dengan keluhan Low Back Pain pada pekerja bagian produksi PT Surya Besindo Sakti Kabupaten Serang (Rohmawan \& Hariyono, 2017).

Menurut asumsi peneliti dari hasil penelitian didapatkan keterangan bahwa mayoritas penjahit di Kecamatan Medan Baru memiliki masa kerja kategori lama dengan keluhan low back pain kategori berat. Penjahit di Kecamatan Medan Baru telah menggeluti pekerjaannya sejak lama dikarenakan mayoritas para penjahit memenuhi kebutuhan seharihari dengan menjadi seorang penjahit. Beberapa penjahit yang memiliki masa kerja dengan kategori baru mengungkapkan bahwa alasannya menjahit untuk memenuhi kebutuhan hidup karena diberhentikan dari pekerjaannya yang lama sebagai dampak dari pandemi Covid-19. Mereka berusaha mencari rezeki dengan menjahit untuk memenuhi kebutuhan hidupnya.

Peneliti menemukan bahwa pada penelitian ini masa kerja tidak memiliki hubungan dengan keluhan low back pain dikarenakan terdapat faktor lain yang lebih berpengaruh terhadap keluhan low back pain seperti usia dan lama kerja. Penjahit dengan masa kerja yang tergolong lama namun selalu bekerja dengan postur tubuh yang baik juga dapat mencegah terjadinya keluhan low back pain.

\section{Analisis Hubungan Lama Kerja dengan Keluhan Low Back Pain Penjahit di Kecamatan Medan Baru}

Waktu kerja bagi seseorang menentukan kesehatan yang bersangkutan, efisiensi, efektivitas, dan produktivitas kerjanya. Memperpanjang waktu kerja lebih dari kemampuan lama kerja tersebut biasanya tidak disertai efisiensi, efektivitas dan produktivitas kerja yang optimal, bahkan biasanya terlihat penurunan kualitas dan hasil kerja serta bekerja dengan waktu berkepanjangan timbul kecenderungan untuk terjadinya kelelahan, gangguan kesehatan, penyakit dan kecelakaan serta ketidakpuasan. 
Hasil penelitian ini sejalan dengan penelitian yang dilakukan oleh Bilondatu (2018) dengan judul "Faktor yang Berhubungan dengan Kejadian Low Back Pain pada Operator Alat Angkat Angkut PT. Terminal Petikemas Makassar" menunjukkan bahwa ada hubungan antara lama kerja dengan low back pain pada Operator PT. Terminal Petikemas Makassar Tahun 2018 (8).

Menurut asumsi peneliti dari hasil penelitian didapatkan keterangan bahwa mayoritas penjahit di Kecamatan Medan Baru memiliki lama kerja kategori kurang sesuai dengan keluhan low back pain kategori berat. Hal ini dikarenakan banyaknya orderan jahit dengan batas waktu sehingga penjahit meneruskan pekerjaannya hingga selesai dan mengurangi efisiensinya dalam bekerja.

Peneliti menemukan bahwa penjahit mengatakan beberapa anggota tubuh mereka lebih terasa sakit jika menjahit dalam waktu yang lama karena gerakan yang diulang secara terusmenerus. Ditambah lagi peneliti melihat bahwa penjahit jarang melakukan peregangan otot disela-sela mereka melakukan pekerjaannya, hal ini tentu sangat memicu terjadinya keluhan low back pain.

\section{Analisis Hubungan Postur Kerja dengan Keluhan Low Back Pain Penjahit di Kecamatan Medan Baru}

Hasil penelitian ini sejalan dengan penelitian yang dilakukan oleh Simanuhuruk (2018) dengan judul "Hubungan antara Postur Kerja dengan Keluhan Nyeri Punggung Bawah Pada Pekerja Penenun Ulos Di Desa Siopatsosor Kecamatan Pangururan Kabupaten Samosir" yang menunjukkan bahwa terdapat hubungan signifikan antara postur kerja dengan keluhan nyeri punggung bawah pada pemanen sawit dengan $p=0,020<0,05$ (Simanihuru, 2018).

Menurut asumsi peneliti dari hasil penelitian didapatkan keterangan bahwa mayoritas penjahit di Kecamatan Medan Baru memiliki postur kerja kategori risiko tinggi dengan keluhan low back pain kategori berat. Hal ini disebabkan karena penjahit tidak memperhatikan postur tubuh mereka ketika menjahit. Mereka terlihat kurang memperdulikan dan menganggap sepele hal tersebut.

Peneliti menemukan bahwa beberapa penjahit menggunakan kursi yang membentuk postur tubuh yang tidak ergonomis. Hal ini tentunya dapat memicu terjadinya keluhan low back pain, untuk itu perlu dirancang sebuah postur kerja dan fasilitas kerja yang ergonomis untuk memberikan kenyamanan kerja pada penjahit dan untuk mencegah keluhan penyakit akibat kerja seperti low back pain sehingga dapat meningkatkan produktivitas kerja.

\section{Pembahasan Analisis Multivariat}

Hasil seleksi kandidat yang dilakukan pada uji bivariat sebelumnya, semua variabel masuk dalam uji regresi binary logistik tahap pertama karena memiliki nilai $p(\operatorname{sig})<0,25$ yaitu usia, jenis kelamin, masa kerja, lama kerja dan postur kerja.

Dari hasil seleksi regresi binary logistik tahap pertama yang digunakan pada uji multivariat terdapat 2 (dua) variabel independen (usia dan lama kerja) yang masuk kedalam model faktor penentu, dikarenakan kedua variabel tersebut memiliki nilai $p(\operatorname{sig})<0,05$ yaitu usia $p$ (Sig) 0,031 dan lama kerja $p$ (Sig) 0,001 .

Dari hasil regresi binary logistik dengan metode enter pada tahap kedua didapatkan hasil variabel usia menunjukan $p$ (Sig) 0,028 dengan nilai OR $(4,915)$ dan variabel lama kerja $p(\operatorname{Sig})$

0,000 dengan nilai OR $(17,170)$

Dapat disimpulkan pada hasil diatas variabel independen (usia dan lama kerja) yang paling berpengaruh terhadap variabel dependen (keluhan low back pain) adalah variabel lama kerja dimana diperoleh nilai OR $(17,170)$ dan $p$ (Sig) 0,000. Ini dikarenakan lama kerja memiliki nilai Exp (B) atau OR paling besar yaitu 17,170, artinya lama kerja penjahit berpeluang 17,170 kali lebih besar mempengaruhi keluhan low back pain Penjahit di 


\section{Kecamatan Medan Baru.}

Persamaan logistik yang didapat dari hasil penelitian ini di gunakan untuk melihat kemampuan variabel independen (usia dan lama kerja) dalam menjelaskan variabel dependen (keluhan low back pain) dengan menggunakan nilai Cox \& Snell R Square dan Nagelkerke R Square. Nilai Cox \& Snell R Square 0,397 dan Nagelkerke R Square sebesar 0,542 , yang menunjukkan bahwa kemampuan variabel independen (usia dan lama kerja) dalam menjelaskan variabel dependen (keluhan low back pain) adalah sebesar 0,542 atau $(54,2 \%)$ dan terdapat $(45,8 \%)$ faktor lain di luar model yang menjelaskan variabel dependen seperti indeks masa tubuh dan gaya hidup responden. Atau persamaan regresi variabel independen (usia dan lama kerja) secara bersama-sama mempengaruhi variabel dependen (keluhan low back pain) sebesar 54,2\%.

\section{Kesimpulan}

Berdasarkan hasil penelitian dengan judul "Hubungan Faktor Individu dan Postur Kerja dengan Keluhan Low Back Pain Penjahit Kecamatan Medan Baru", yang telah disajikan dapat disimpulkan bahwa ada hubungan usia dengan keluhan Low Back Pain Penjahit Kecamatan Medan Baru. Usia berhubungan dengan keluhan Low Back Pain dikarenakan semakin bertambahnya usia maka semakin besar kemungkinan seseorang untuk mengalami keluhan Low Back Pain yang disebabkan kekuatan dan ketahanan otot mulai menurun sehingga risiko terjadinya keluhan otot semakin meningkat yang dapat berdampak pada efektivitas kerja, ada hubungan jenis kelamin dengan Keluhan Low Back Pain Penjahit Kecamatan Medan Baru. Jenis kelamin berhubungan dengan keluhan Low Back Pain dikarenakan kemampuan otot wanita lebih rendah dibandingkan dengan lakilaki. Seluruh penjahit wanita telah mengalami proses menstruasi, mayoritas penjahit wanita sudah menikah dan mengalami proses bersalin dan menyusui. Selain itu, beberapa penjahit wanita mengaku sudah berada pada fase menopause, tidak ada hubungan masa kerja dengan Keluhan Low Back Pain Penjahit Kecamatan Medan Baru. Masa kerja tidak berhubungan dengan keluhan Low Back Pain dikarenakan faktor lain yang lebih berpengaruh terhadap keluhan low back pain seperti usia dan lama kerja, ada hubungan lama kerja dengan Keluhan Low Back Pain Penjahit Kecamatan Medan Baru. Lama kerja berhubungan dengan keluhan Low Back Pain dikarenakan lama kerja penjahit yang kurang sesuai sebab banyaknya orderan jahit dengan batas waktu sehingga penjahit meneruskan pekerjaannya hingga selesai dan mengurangi efisiensinya dalam bekerja, ada hubungan postur kerja dengan Keluhan Low Back Pain Penjahit Kecamatan Medan Baru. Postur kerja berhubungan dengan keluhan Low Back Pain dikarenakan penjahit tidak memperhatikan postur tubuh mereka ketika menjahit. Mereka terlihat kurang memperdulikan dan menganggap sepele hal tersebut, hasil uji regresi logistik variabel yang paling berpengaruh terhadap Keluhan Low Back Pain adalah lama kerja penjahit berpeluang 17,170 kali lebih besar mempengaruhi dengan Keluhan Low Back Pain Penjahit di Kecamatan Medan Baru.

\section{Daftar Pustaka}

Aminoto TA, L. AB, L. AB. (2017). Pengaruh Faktor Risiko Ergonomi Terhadap Keluhan Nyeri Punggung Bawah (Low Back Pain) Pada Karyawan Bushindo Training Center Jakarta Timur. J Ilmu dan Teknol Kesehat. 4(2):189-94.

Ayu F, Ayu R. (2018). Sosialisasi Teknik Mengurangi Nyeri Tulang Panggung BAwah (Low Back Pain) pada Pengemudi Bus Antarkota Antarprovinsi (AKAP) di Terminal Bungurasih. Fak Kesehat Univ Nahdlatul Ulama Surabaya. 
Bilondatu F. (2018). Faktor Yang Berhubungan Dengan Kejadian Low Back Pain Pada Operator PT. Terminal Petikemas Makassar. Fakultas Kesehatan Masyarakat Universitas Hasanuddin Makassar.

Damayanti PJ, (2021). Faktor yang berhubungan dengan keluhan low back pain pada penjahit sebuah kajian literatur artikel. Studi P, Masyarakat K, Kesehatan FI, Surakarta UM.

Jahidin A. (2009). Hubungan Lama Dan Posisi Duduk Dengan Keluhan Nyeri Punggung Bawah Pada Penjahit Baju Di Pasar Sentral Polewali Dan Pasar Wonomulyo Kabupaten Polewali Mandar.

Nurul Isriyanti AR. (2019). Gambaran Aktivitas Penjahit Dengan Keluhan Low Back Pain Ditinjau Dari Segi Ergonomi Di Pasar Sentral. 19(2):246-50.

Riningrum H. (2016). Pengaruh Sikap Kerja, Usia, dan Masa Kerja Terhadap Keluhan Subyektif Low Back Pain pada Pekerja Bagian Sewing Garmen PT. APAC Inti Corpora Kabupaten Semarang. Skripsi Univ Negeri Semarang.

Rohmawan E A, Hariyono W. (2017). Masa Kerja, Sikap Kerja Dan Keluhan Low Back Pain (LBP) Pada Pekerja Bagian Produksi PT Surya Besindo Sakti Serang. Prosiding Seminar Nasional IKAKESMADA "Peran Tenaga Kesehatan dalam Pelaksanaan SDGs".

Simanihuruk S.(2018). Hubungan Sikap Kerja Dengan Keluhan Nyeri Punggung Bawah Pada Pekerja Penenun Ulos Di Desa Siopatsosor Kecamatan Pangururan Kabupaten Samosir. Universitas Sumatera Utara.

Sujono, Raharjo W, Fitriangga A. (2018). Hubungan antara Posisi Kerja terhadap Low Back Pain pada Pekerja Karet Bagian Produksi di PT. X Pontianak. J Cerebellum [Internet]. 4(2):1037-51. Available from: https://jurnal.untan.ac.id/index.php/jfk/article/viewFile/29453/75676579043

Ulandari S. (2017). Analisis Postur Kerja dengan Keluhan Low Back Pain Pada Pekerja Pencetak Genteng di Kabupaten Blitar. Repository Universitas Jember.

Wijayanti F, Oktafany, Ramadhian RM, Saftarina F, Cania E. (2019). Kejadian Low Back Pain ( LBP ) pada penjahit konveksi di kelurahan Way Halim kota Bandar Lampung. Medula [Internet]. 8:82-8. Available from: http://repository.lppm.unila.ac.id/13036/1/ergonomi.pdfAyu F, Ayu R. Sosialisasi Teknik Mengurangi Nyeri Tulang Panggung BAwah (Low Back Pain) pada Pengemudi Bus Antarkota Antarprovinsi (AKAP) di Terminal Bungurasih. Fak Kesehat Univ Nahdlatul Ulama Surabaya. 